\title{
RESPON TANAMAN KEDELAI (Glycine max Merr) TERHADAP JUMLAH AIR YANG DIBERIKAN
}

\author{
Response Of Soybean (Glycine Max Merr) On Total Water Provided
}

\author{
W. Guntoro, Hadi Suhardjono, Ida Retno Moeljani dan Agus Sulistyono \\ Fakultas Pertanian UPN Veteran Jawa Timur \\ e-mail: ${ }^{1}$ email@upnjatim.ac.id, ${ }^{2}$ email@upnjatim.ac.id, \\ 3idarm.upnjatim@gmail.com, ${ }^{4}$ agussmkponpes@gmail.com,
}

\begin{abstract}
ABSTRAK
Kekurangan air merupakan masalah yang sering dijumpai pada pertanaman kedelai. Umumnya tanaman kedelai ditanam pada musim kemarau dan atau pada lahan kering beriklim kering. Tanaman kedelai produksinya sangat ditentukan oleh jumlah dan distribusi curah hujan yang tidak merata dalam musim tanam. Kemampuan tanaman untuk hidup pada kondisi kekurangan air merupakan keberhasilan suatu tanaman untuk menyesuaiakan diri. Tujuan penelitian ini untuk mengetahui pengaruh jumlah air yang diberikan terhadap pertumbuhan tanaman kedelai. Penelitian dilakukan di Balai Benih Induk Palawija Malang. Rancangan yang digunakan adalah rancangan acak kelompok yang diulang tiga kali, dan terdiri dari tiga macam perlakuan yakni : Jumlah air yang diberikan setaraf kapasitas lapang (A1), setengah kapasitas lapang (A2), dan seperempat kapasitas lapang (A3). Hasil penelitian menunjukkan bahwa terdapat perbedaan yang nyata pada variabel pertumbuhan yakni tinggi tanaman, jumlah daun, luas daun, panjang akar dan berat kering akar. Perlakuan terbaik adalah perlakuan A1 atau jumlah air yang diberikan setaraf dengan kapasitas lapang untuk masing-masing variabel tinggi tanaman $(83,50 \mathrm{~cm})$, jumlah daun $(19,00)$, luas daun $(835$ $\left.\mathrm{cm}^{2}\right)$, panjang akar $(592,86 \mathrm{~mm})$ dan berat kering akar $(0,24 \mathrm{~g})$.
\end{abstract}

Kata kunci : Glycine max Merr, kapasitas lapang, jumlah air

\section{ABSTRACT}

Lack of water is a problem frequently encountered in soybean because in general the soybean crop planted in dry season and dry land or in dry climates whose production is largely determined by the amount and distribution of rainfall is not evenly distributed in the growing season. The ability of plants to live under conditions of water shortage is the success of a plant for menyesuaiakan themselves.

The purpose of this study is to determine the extent of the influence of the amount of water supplied to the growth of soybean plants. The study was conducted at the Center for Parent Seed Crops Malang. The design used was a randomized block design that is repeated three times, and consists of three kinds of treatment that is: given equal amount of water field capacity (A1), half of field capacity (A2), and a quarter of field capacity (A3).The results showed that there were significant differences in the growth variables plant height, leaf number, leaf area, root length and root dry weight. The best treatment is the treatment of A1 or the amount of water supplied to the field capacity equal to each of the variables plant height $(83.50 \mathrm{~cm})$, number of leaves $(19,00)$, leaf area $(835 \mathrm{~cm} 2)$, root length $(592.86 \mathrm{~mm})$ and root dry weight $(0.24 \mathrm{~g})$. 
Key words: Glycine max Merr, field capacity, the amount of water

\section{PENDAHULUAN}

Kekurangan air merupakan masalah yang sering dijumpai pada pertanaman kedelai. Umumnya tanaman kedelai ditanam pada musim kemarau dan atau pada lahan kering beriklim kering. Tanaman kedelai produksinya sangat ditentukan oleh jumlah dan distribusi curah hujan yang tidak merata dalam musim tanam (Boer, Las dan Notodipuro, 1998). Pengembangan tanaman kedelai sangat diperlukan sejalan dengan peningkatan konsumsi bahan makanan dan industri yang memerlukan bahan baku kedelai, sementara produksi kedelai tidak mencukupi (Baharsjah, dkk, 1993).

Kemampuan tanaman untuk hidup pada kondisi kekurangan air merupakan keberhasilan suatu tanaman untuk menyesuaikan diri. Mekanisme untuk mempertahankan diri tersebut diantaranya ditempuh melalui penutupan stomata. Stomata mempunyai peranan penting sebagai pintu keluar masuknya uap air, gas oksigen, $\mathrm{CO}_{2}$, gas-gas polutan maupun suatu senyawa dari dan ke dalam daun. Proses penutupan stomata tersebut dapat menimbulkan dampak positif karena dapat menekan kehilangan air dari dalam tubuh tanaman, tetapi dari aspek pertumbuhan berdampak negatif, karena proses difusi $\mathrm{CO}_{2} \mathrm{ke}$ dalam jaringan daun terhambat akibatnya proses fotosintesis terganggu, produk fotosintesis menurun, sintesis protein menurun dan berakibat biomasa dan hasil biji rendah (Davies, et all, 1981; Salisbury dan Ross, 1995; Serraj, et all.1999).

\section{METODE PENELITIAN}

Penelitian ini dilakukan, di Balai Benih Induk Palawija, Kecamatan Lawang, Kabupaten Malang.

Percobaan ini disusun dalam Rancangan Acak Kelompok (RAK) yang diulang tiga kali, dan terdiri tiga macam perlakuan yakni : jumlah air yang diberikan setaraf kapasitas lapang (A1), setengah kapasitas lapang (A2), dan seperempat kapasitas lapang (A3). Bahan dalam penelitian ini adalah : benih kedelai varietas Wilis. Data dianalisis dengan Analisis Ragam dan dilanjutkan dengan Uji Nilai Tengah yaitu BNT 5\%.

\section{HASIL DAN PEMBAHASAN}

\section{Hasil Penelitian}

\section{Tinggi Tanaman}

Data hasil analisis statistika menunjukkan bahwa tidak terjadi perbedaan yang nyata $(\mathrm{p}=0,05)$ pada berbagai macam perlakuan jumlah air yang diberikan terhadap tinggi tanaman kedelai pada umur 15 dan 25 hari setelah tanam. Sedangkan pada umur 35, 45 dan 55 hari setelah tanam menunjukkan adanya perbedaan yang nyata terhadap tinggi tanaman kedelai, 
dan data rata-rata tinggi tanaman kedelai pada umur 15, 25, 35, 45 dan 55 hari setelah tanam tercantum pada Tabel 1 .

Tabel 1. Rata-rata Tinggi Tanaman (cm) Kedelai pada Berbagai Macam Jumlah Air yang Diberikan pada Umur 15, 25, 35, 45, dan 55 HST

\begin{tabular}{lccccc}
\hline Perlakuan & $15 \mathrm{HST}$ & 25 HST & 35 HST & $45 \mathrm{HST}$ & $55 \mathrm{HST}$ \\
\hline A1 & $18.43 \mathrm{a}$ & $31.83 \mathrm{a}$ & $59.75 \mathrm{c}$ & $66.83 \mathrm{c}$ & $83.50 \mathrm{c}$ \\
A2 & $17.77 \mathrm{a}$ & $29.17 \mathrm{a}$ & $47.83 \mathrm{~b}$ & $56.75 \mathrm{~b}$ & $66.75 \mathrm{~b}$ \\
A3 & $16.47 \mathrm{a}$ & $27.83 \mathrm{a}$ & $38.83 \mathrm{a}$ & $43.56 \mathrm{a}$ & $53.58 \mathrm{a}$ \\
\hline BNT 5\% & 0.53 & 6.17 & 6.34 & 5.27 & 8.31 \\
\hline Keterangan: & Angka-angka yang diikuti huruf yang sama pada setiap perlakuan tidak berbeda nyata \\
& menurut uji BNT 5\% \\
& A1 : Jml air yang diberikan setaraf kapasitas lapang & \\
& A2 : Jml air yang diberikan setaraf setengah kapasitas lapang & \\
& A3 : Jml air yang diberikan setaraf seperempat kapasitas lapang &
\end{tabular}

Jumlah Daun.

Data hasil analisis statistika menunjukkan bahwa tidak terjadi perbedaan yang nyata $(\mathrm{p}=0,05)$ pada berbagai macam perlakuan jumlah air yang diberikan terhadap jumlah daun tanaman kedelai pada umur 15 dan 25 hari setelah tanam. Sedangkan pada umur 35, 45 dan 55 hari setelah tanam menunjukkan adanya perbedaan yang nyata terhadap tinggi tanaman kedelai (Tabel lampiran 8, 9 dan 10), dan data rata-rata jumnlah daun tanaman kedelai pada umur 15, 25, 35, 45 dan 55 hari setelah tanam tercantum pada Tabel 2.

Tabel 2. Rata-rata Jumlah Daun Tanaman Kedelai pada Berbagai Macam Jumlah Air yang Diberikan pada Umur 15, 25, 35, 45, dan 55 HST

\begin{tabular}{lccccc}
\hline Perlakuan & $15 \mathrm{HST}$ & 25 HST & 35 HST & $45 \mathrm{HST}$ & 55HST \\
\hline A1 & $2.00 \mathrm{a}$ & $4.67 \mathrm{a}$ & $8.67 \mathrm{c}$ & $14.67 \mathrm{c}$ & $19.00 \mathrm{c}$ \\
A2 & $1.87 \mathrm{a}$ & $4,00 \mathrm{a}$ & $7.00 \mathrm{~b}$ & $9.67 \mathrm{~b}$ & $15.33 \mathrm{~b}$ \\
A3 & $1.87 \mathrm{a}$ & $3.67 \mathrm{a}$ & $5.33 \mathrm{a}$ & $7.67 \mathrm{a}$ & $12.67 \mathrm{a}$ \\
\hline BNT 5\% & 0.003 & 0.185 & 0.444 & 0.556 & 0.444 \\
\hline Keterangan: & Angka-angka yang diikuti huruf yang sama pada setiap perlakuan tidak berbeda nyata \\
& menurut uji BNT 5\% & & \\
& A1 : Jml air yang diberikan setaraf kapasitas lapang & & \\
& A2 : Jml air yang diberikan setaraf setengah kapasitas lapang & & \\
& A3 : Jml air yang diberikan setaraf seperempat kapasitas lapang
\end{tabular}

\section{Luas Daun.}

Data hasil analisis statistika menunjukkan bahwa tidak terjadi perbedaan yang nyata $(\mathrm{p}=0,05)$ pada berbagai macam perlakuan jumlah air yang diberikan terhadap luas daun tanaman kedelai pada umur 15 dan 25 hari setelah tanam. Sedangkan pada umur 35, 45 dan 55 hari setelah tanam menunjukkan adanya perbedaan yang nyata terhadap tinggi tanaman kedelai (Tabel lampiran 13, 14 dan 15), dan data rata-rata jumnlah daun tanaman kedelai pada umur 15, 25, 35, 45 dan 55 hari setelah tanam tercantum pada Tabel 3. 
Tabel 3. Rata-rata Luas Daun $\left(\mathrm{cm}^{2}\right)$ Tanaman Kedelai pada Berbagai Macam Jumlah Air yang Diberikan pada Umur 15, 25, 35, 45, dan 55 HST

\begin{tabular}{lccccc}
\hline Perlakuan & 15 HST & 25 HST & 35 HST & $45 \mathrm{HST}$ & 55HST \\
\hline A1 & $50.43 \mathrm{a}$ & $143.50 \mathrm{a}$ & $418.33 \mathrm{a}$ & $710.00 \mathrm{c}$ & $835.00 \mathrm{c}$ \\
A2 & $43.67 \mathrm{a}$ & $122.83 \mathrm{a}$ & $258.00 \mathrm{~b}$ & $527.33 \mathrm{~b}$ & $725.67 \mathrm{~b}$ \\
A3 & $40.33 \mathrm{a}$ & $109.17 \mathrm{a}$ & $216.00 \mathrm{c}$ & $296.17 \mathrm{a}$ & $560.00 \mathrm{a}$ \\
\hline BNT 5 \% & 11.214 & 49.697 & 19.356 & 19.404 & 13.862
\end{tabular}

Keterangan: Angka-angka yang diikuti huruf yang sama pada setiap perlakuan tidak berbeda nyata menurut uji BNT 5\%

A1 : Jml air yang diberikan setaraf kapasitas lapang

A2 : Jml air yang diberikan setaraf setengah kapasitas lapang

A3 : Jml air yang diberikan setaraf seperempat kapasitas lapang

\section{Panjang Akar dan Berat Kering Akar.}

Data hasil analisis statistika menunjukkan bahwa tidak terjadi perbedaan yang nyata $(\mathrm{p}=0,05)$ pada berbagai macam perlakuan jumlah air yang diberikan terhadap panjang akar dan berat kering akar tanaman kedelai pada umur panen dan data rata-rata panjang akar dan berat kering akar tanaman kedelai pada umur panen tercantum pada Tabel 4.

Tabel 4. Rata-rata Panjang Akar (mm) Dan Berat Kering Akar (g) Tanaman Kedelai pada Berbagai Macam Jumlah Air yang Diberikan pada Umur Panen

\begin{tabular}{|c|c|c|}
\hline Perlakuan & Panjang Akar & $\begin{array}{c}\text { Berat Kering } \\
\text { Akar }\end{array}$ \\
\hline A1(Jml air setaraf kapasitas lapang) & $592.86 \mathrm{a}$ & $0.24 \mathrm{a}$ \\
\hline A2 (Jml air setaraf setengah kapasitas lapang) & $579.69 \mathrm{a}$ & $0.21 \mathrm{a}$ \\
\hline A3 (Jml air setaraf seperempat kapasitas lapang) & $566.52 \mathrm{a}$ & $0.17 \mathrm{a}$ \\
\hline BNT $5 \%$ & 2126.286 & 0.004 \\
\hline
\end{tabular}

\section{Pembahasan}

Berdasarkan hasil pengamatan dan analisis statistika (Uji F dan BNT 5\%) dapat diketahui bahwa pengaruh pemberian jumlah air yang diberikan secara nyata terjadi setelah tanaman berumur 35 hari setelah tanam (pada variabel tinggi tanaman, jumlah daun dan luas daun), hal ini disebabkan tanaman pada waktu usia muda (dibawah 35 hari) mempunyai kebutuhan yang relatif sedikit, semakin bertambahnya umur tanaman semakin bertambah pula kebutuhan air untuk melangsungkan proses metabolisme di dalam tubuh tanaman, pada kondisi kekurangan tanaman akan mengalami gangguan dalam prosese metabolismenya sehingga tanaman akan memberikan respon yang berbeda dengan kondisi pemberian yang berbeda pula. Pada prinsipnya tanaman akan melakukan recovery semaksimal mungkin akibat kondisi eksternal yang ekstreem (Levitt, 1980; Maynard dan David, 1987; Bohner dan Jansen, 1996). Dari perlakuan-perlakuan jumlah air yang berbeda menunjukkan bahwa pada air kapasitas lapang masih tetap merupakan kondisi yang terbaik untuk pertumbuhan tanaman kedelai, sedang perlakuan setengah kapasitas (50 \%) menunjukkan perbedaan yang nyata 
dibanding dengan perlakuan seperempat (25\%) kapasitas lapang, hal ini menandakan bahwa semakin berkurangnya ketersediaan air akan semakin menurunkan pertumbuhan tanaman. Pada variabel pengamatan panjang dan berat kering akar ternyata perlakuan pemberian air tidak menunjukkan perbedaan nyata, kemampuan akar dalam menyerap air juga dipengaruhi oleh kondisi tekstur tanah dimana akar tanaman tersebut tumbuh, kondisi tekstur yang remah dan gembur akan mempermudah akar dalam upaya menyerap air.

Terjadinya kekeringan atau kondisi kurangnya ketersediaan air bagi tanaman secara teoritis akan mempengaruhi hampir seluruh tahapan proses metabolisme di dalam tubuh tanaman. Tanaman kedelai mempunyai tahapan-tahapan yang spesifik didalam pertumbuhannya dimulai dengan terbentuknya kecambah sampai dengan fase pemasakan biji dalam polong, rangkaian fase ini dikenal dengan rangkaian V1-Vn dan R1 - R7 (R8) dengan periode antar fase yang bisa sama ataupun berbeda tergantung varietas kedelai ( Turner, 1986; Xia, 1994). Hasil penelitian diketahui bahwa pada masing-masing fase ini menunjukkan tidak adanya perbedaan yang nyata pada semua variabel pengamatan yang diamati, hal ini diduga disebabkan setiap fase pertumbuhan kedelai mempunyai respon yang sama terhadap pengaruh lingkungan eksternal seperti pemberian air, walaupun menunjukkan kecenderungan fase generatif merupakan fase yang sensitif terhadap pengaruh kondisi eksternal.

Penampilan fenotip suatu tanaman disamping dipengaruhi oleh kondisi lingkungan eksternal juga sangat tergantung dari kemampuan daya adaptasi tanaman pada masingmasing tahapan pertumbuhan dan jenis atau varietas tanaman, pada tanaman kedelai pada umumnya fase pertumbuhan yang paling sensitif terhadap perubahan - perubuahan lingkungan eksternal yang ekstreem terletak pada saat memasuki fase generatif (Shimshi et all. 1982; Taiz dan Zeiger, 1995).

\section{KESIMPULAN DAN SARAN}

Hasil penelitian menunjukkan bahwa pemberian jumlah air yang berbeda memberikan pengaruh yang berbeda pula terhadap pertumbuhan tanaman kedelai, tanaman memberikan respon yang nyata terhadap pemberian air setelah tanaman mulai memasuki fase generatif (mulai berumur 35 hari setelah tanam) dan pemberian air pada seperempat ( $25 \%$ ) dari kapasitas lapang menunjukkan pertumbuhan tinggi tanaman, jumlah dan luas daun yang terendah, tetapi perlakuan jumlah air tidak memberikan pada pengamatan panjang dan berat kering akar.

Perlakuan fase pertumbuhan tanaman kedelai ternyata memberikan respon yang sama terhadap perlakuan eksternal (pemberian air dan sorbitol) tetapi menunjukkan adanya kecenderungan pada fase generatif (R3-R7) merupakan fase yang sensitif. 


\section{DAFTAR PUSTAKA}

Baharsjah, J.S., Suardi, D., dan Las, I. 1993. Hubungan Iklim dengan Pertumbuhan Kedelai dalam S. Somaatmadja et al (ED). Kedelai. Pusat Penelitian dan Pengembangan Tanaman Pangan Bogor, hlm 87 - 102.

Boer, R; Las, I., dan Notodipuro, K.A. 1998. Analisis Resiko Kekeringan untuk Pengembangan dan Produksi Kedelai di Flores, Nusa Tenggara Timur. Laporan Riset. Riset Ungulan Terpadu IV (1996 - 1998) Kantor Menristek Dewan Riset Nasional. Hlm. $26-31$.

Bohner, H.J., and J.G. Jansen, 1996. Strategies for Enginering Water Stress Tolerance in Plant. TBTECH. 14:89-97.

Davies,M.T., J.A., Wilson, R.E. Sharp., and O. Osonubi. 1981. Control of Stomatal Behaviour in Water Stressed Plants. Soc, For Biology Seminar Series 8 : 163-181.

Levitt, J. 1980. Responses of Plant to Environmental Stress. Academic Press. 227 p.

Maynard, G. Hale and David M.Orcutt. 1987. The Physiology of Plant Under Stress. A. Wiley-Interscience Publication. John Willey \& Sons New York 206 p.

Salisbury, F.B. and C. Ross. 1995. Plant Physiology. Wadsworth Pub.Co.Inc. California. 747 p.

Serraj, R. L.H.Allen Jr. and T.R Sinclair. 1999. Effects of Elevated $\mathrm{CO}_{2}$ and Water Stress on Soybean. Global Change Biology 5:283-291.

Shimshi, D., M.L.Mayoral and D. Atsmon. 1982. Response to Water Stress in Wheat and Related Wild Species. Crop.Sci. 22:161-167

Taiz, L. and E. Zeiger. 1995. Plant Physiology. The Benjamin/Cummings Publ.Co. California ; 1 - 39.

Turner, C.N. 1986. Crop Water Deficite. A Decade of Progress. Adv. In Agron. 39 ; 1-39

Xia, M.Z. 1994. Effects of Soil Drougth During The Generative Development Phase of Faba Bean (Vicia faba) on Photosynthetic Characters and Biomass Production. Journal of Agricultural Science. Cambridge 1994 February;122(1);67-72. 